\title{
Seasonal, daily activity, and habitat use by three sympatric pit vipers (Serpentes, Viperidae) from southern Brazil
}

\author{
MARCELO C. ROCHA ${ }^{1, *}$, PAULO A. HARTMANN ${ }^{2}$, GISELE R. WINCK ${ }^{3}$ and SONIA Z. CECHIN ${ }^{4}$ \\ ${ }^{1}$ Pós-Graduação em Biodiversidade Animal, Centro de Ciências Naturais e Exatas, Universidade Federal de Santa Maria, \\ Av. Roraima, 1000, Prédio 17, sala 1140, Camobi, 97105-900 Santa Maria, RS, Brasil \\ ${ }^{2}$ Universidade Federal da Fronteira Sul, Campus Erechim, Avenida Dom João Hoffman, 313, 99700-000 Erechim, RS, Brasil \\ ${ }^{3}$ Universidade do Estado do Rio de Janeiro, Instituto de Biologia Roberto de Alcântara Gomes, Departamento de Ecologia, \\ Rua São Francisco Xavier, 524, Pavilhão Haroldo Lisboa, sala 220, Maracanã, 20550-019 Rio de Janeiro, RJ, Brasil \\ ${ }^{4}$ Universidade Federal de Santa Maria, Centro de Ciências Naturais e Exatas, Departamento de Biologia, \\ Av. Roraima 1000, Prédio 17, sala 1140, Camobi, 97105-900 Santa Maria, RS, Brasil
}

Manuscript received on November 12, 2012; accepted for publication on May 5, 2013

\begin{abstract}
Viperid snakes are widely distributed in the South America and the greater distribution range of the family is found at the Crotalinae subfamily. Despite the abundance of this snakes along their geographic distribution, some ecological aspects remain unknown, principally at subtropical areas. In the present study, we evaluated the activity (daily and seasonal) and the use of the habitat by Bothrops diporus, B. jararaca and B. jararacussu, in an Atlantic Forest area at southern Brazil. We observed higher incidence of viperid snakes during the months with higher temperatures, while no snakes were found during the months with lower temperatures. The data suggest the minimum temperature as environmental variable with the greatest influence on the seasonal activity of this species. Considering the daily activity, we observed a tendency of snakes to avoid the warmest hours. Bothrops jararacussu tend to avoid open areas, being registered only inside and at the edges of the forest. We compared our results with previous studies realized at tropical areas and we suggest the observed seasonal activity as an evolutive response, despite the influence of the different environmental variables, according to the occurence region.
\end{abstract}

Key words: Parque Estadual do Turvo, Rio Grande do Sul, Atlantic Forest, Bothrops, activity pattern.

\section{INTRODUCTION}

Ecological studies using snakes as a model organism have become more frequent in recent decades (e.g., Huey et al. 1989, Shine and Bonnet 2000, Blouin-Demers and Weatherhead 2001, Miller et al. 2011), mainly due to their greater

\footnotetext{
Correspondence to: Marcelo C. Rocha

E-mail: marcelomicrurus@gmail.com

* Present address: Universidade Regional Integrada do Alto Uruguai e das Missões, URI Campus de Frederico Westphalen, Avenida Assis Brasil, 709, 98400-000 Frederico Westphalen, RS, Brasil
}

plasticity in habitat use, behavior, and ecology, when compared to other vertebrate groups (e.g., Ford and Siegel 1989, Madsen and Shine 1993). In addition, information about their natural history are important for understanding the wide variety of habits that many species have adopted through their life story, generating important data for employing conservation measures (Greene 1997).

The family Viperidae is widely spread, with more diversity in the tropics of Central America, South America and Southeast Asia (see Campbell 
and Lamar 2004). Most radiation occurred within the subfamily Crotalinae, and in South America representatives can be found in all ecosystems (Martins et al. 2001). In Brazil, the members of this subfamily are generally abundant in inventories and studies of snake assemblages (Martins and Oliveira 1998, Santos et al. 2005, Zanella and Cechin 2006, Pontes et al. 2008, Sawaya et al. 2008, Hartmann et al. 2009a, b, Guizoni-Jr et al. 2009, Centeno et al. 2008), with exceptions (e.g., Winck et al. 2007, Martins et al. 2012). However, studies are still incipient in remnants of Atlantic Forest in southern Brazil, where Bothrops diporus (Cope 1862), Bothrops jararaca (Wied 1824), and Bothrops jararacussu Lacerda, 1884 occur in sympatry.

Closely related species that occur in sympatry usually differ in some degree in some of the major axes of the hyper-dimensional niche (sensu Hutchinson 1959): time, space, and food (see Pianka 1986). Regarding space use, some species are more adapted to inhabit different types of vegetation (e.g., natural or degraded, more closed or more opened), and these limitations are mainly related to several features of the species natural history (e.g., nest site, alimentary resource, thermal regulation) (see Gibbons and Semlistch 1987, Martins et al. 2001, Hartmann and Marques 2005). In terms of temporal activity, snake species may vary over the year (seasonally) and throughout the day. Snakes of sites with temperate climates tend to show more restrictions on seasonal activity than the tropical species (May et al. 1996) because in most cases seasonality is related to the breeding activities (see Mushinsky 1987). Meanwhile, daily activity tends to be more related to the activities of foraging and thermoregulation (see Gibbons and Semlistch 1987). Studies with Bothrops in tropical areas usually classified them as nocturnal snakes, with activity peak corresponding to the rainy season (Campbell and Lamar 2004). In southern Brazil, the data on viperids are still incipient, with most studies designed to recognize patterns related to reproduction, seasonal activity (e.g., Hartmann et al. 2004), and diet and habitat use (e.g., Hartmann et al. 2005). In the present study, we sought to assess the habitat use by three sympatric species of the genus Bothrops. We also pursued to elucidate if the pattern of seasonal and daily activity of three species in subtropical Brazilian territory is similar to the known congeneric species occurring in tropical climate.

\section{MATERIALS AND METHODS}

STUDY AREA

The study was conducted in Turvo State Park (Parque Estadual do Turvo, PET), situated in the northwest region of the state of Rio Grande do Sul, Brazil $\left(27^{\circ} 07^{\prime}-27^{\circ} 16^{\prime} \mathrm{S} ; 53^{\circ} 48^{\prime}-54^{\circ} 04^{\prime} \mathrm{W}\right)$. The area has a variation in altitude between 100 and $400 \mathrm{~m}$, belonging to the municipality of Derrubadas. With 17,491 ha, the conservation unit is inserted within the Atlantic Forest biome domain (Instituto Brasileiro de Geografia e Estatística, IBGE 2010). The vegetation type is semi-deciduous forest, belonging to the Misiones core dominion in seasonal tropical (TSFR; sensu Prado 2000), and represents the largest remaining area of such vegetation in the state (Secretaria do Meio Ambiente do Estado do Rio Grande do Sul, SEMA 2005).

The climate in PET is characterized as subtropical sub-humid with dry summer (Maluf 2000). During the study the average temperature was $20.5^{\circ} \mathrm{C}$, with two seasons defined by temperature. The first, with higher temperatures, comprised the months from November to March, with an average of $25^{\circ} \mathrm{C}$. The second, corresponded to the season with lower temperatures, and ranged from May to September, with average temperature of $15.7^{\circ} \mathrm{C}$. Rainfall during the study period was $2231.8 \mathrm{~mm}$, with monthly averages of $185.9 \mathrm{~mm}$. The months of lowest rainfall were April and June, with 26.20 $\mathrm{mm}$ and $42.5 \mathrm{~mm}$, respectively. Climatic data during this study were obtained from the National Institute of Meteorology (Instituto Nacional de 
Meteorologia, INMET 2010) from the weather station situated in the city of Iraí, $56 \mathrm{~km}$ distant from the study area. Data comprised temperature (mean monthly minimum, monthly average, and maximum monthly average), precipitation (monthly rainfall) and insolation.

\section{SAMPLING}

We conducted one year of monthly sampling during 10 days (from April, 2009 to March, 2010) in areas pertaining to PET, and in surrounding areas. The categories of vegetation considered for this study included: i) forest interior, at least $1 \mathrm{~km}$ away from the edges of the conservation unit, which influence the natural hydroperiod of the ponds of the PET; ii) forest edge, which comprise transitional environments between the areas of cultivation and forest; and iii) degraded areas, which correspond to the matrix surrounding the conservation area with degraded natural vegetation and/or replaced by cultivation or pastures. For analyzis of daily activity, we considered the time of day as a sample, while for seasonal analysis, we considered the months as samples (total of samples $=12$ ). To avoid the bias of the different number of sampled hours of day and night, we calculated the rate of activity of these periods (day and night) as the number of minutes divided by recorded snakes within 24 hours (day $=$ 660 minutes; night $=360$ minutes). To capture the snakes, we used different methods in combination: pitfall traps with drift-fence, time-constrained search, road search, support of registered workers, and occasional encounters. The pitfall traps (Cechin and Martins 2000) were installed in eight stations, each consisting of a row of four plastic containers of $0.8 \times 0.4 \mathrm{~m}$ (height $\mathrm{x}$ diameter), with a capacity of 136 liters, buried in the ground level, placed every $15 \mathrm{~m}$, and united by a plastic fence with height of $0.75 \mathrm{~m}$. In total we used 32 containers and about 480 $\mathrm{m}$ of drift-fences. Four stations were placed in forest edge, $20 \mathrm{~m}$ far from the opened vegetation area. Other four stations were placed in forest interior, three kilometers far from forest edge. Each station was placed at least a kilometer apart from the nearest one. The traps were opened 24 hours previous to first review, and remained open uninterruptedly during five days per month. The traps were checked each morning, and the sampling effort was measured in hours of open traps. To accomplish time-constrained search (TCS) (Martins and Oliveira 1998), we walked through transects without pre-defined orientation with slow dislocation in each vegetation category considered. Sampling using TCS was accomplished for three hours during the day (between 08:0012:00 or 14:00-19:00 hours) and three hours at night (between 19:00-24:00 hours), dispensing the same effort at all daily hours. The sampling effort and the rate of encounter of snakes were measured in personhours of visual search. During road search (ROS) (Hartmann et al. 2011) we recorded the number of active snakes (e.g., dislocation, basking, etc.) in roads inside PET as well as the roads around the park. During sampling, the forward speed was up to $30 \mathrm{~km} / \mathrm{h}$. The sampling effort was quantified in kilometers driven. Records made by registered workers (RW) (Bernarde and Abe 2006) were performed by local residents trained to handle snakes and to collect individual data. Residents were equipped with protective items, trained for handle the animals, and properly registered at the licensor organ (SEMA and Instituto Brasileiro de Meio Ambiente e dos Recursos Naturais Renováveis IBAMA). We considered occasional encounters (OE) those records done during offhours search (TCS and ROS) (Sawaya et al. 2008, Hartmann et al. 2009a).

We consider snakes to be active when dislocating, or exposed with the neck in the shape of "S" and with the head forming an angle of up to $20^{\circ}$ to the ground performing stalking activity (Oliveira and Martins 2001). Snakes were considered inactive when they were sheltered, or neck flat against the body forming an angle of less than $20^{\circ}$ relative to the ground (Oliveira and Martins 2001). 


\section{DATA ANALYSIS}

To compare the abundance of viperids and environmental variables (minimum temperature, rainfall and insolation), we used multiple linear regression. To this end, climate data and abundance were transformed into logarithm $(\ln )$ to ensure homoscedasticity of data (Zar 1999). To calculate the rate of encounter in day and night periods, we used the number of captures divided by minutes of sampling over 24 hours. To statistical analysis, we utilized the software Statistica 8.0 (STATSOFT 19842006). To analyze the use of mesohabitats by snakes (degraded area, forest edge and forest interior) we utilized analysis of variance via data randomization (see Legendre and Legendre 1998) with 10,000 iterations. Each specimen was considered a sample $(\mathrm{N}=97$; G.L. $=96)$, and each species as a group $\left(\mathrm{N}_{\text {groups }}=3\right)$. As resemblance measure, we utilized Gower index. This analysis was conducted through MULTIV 2.78b (Pillar 2006).

\section{RESULTS}

We recorded 97 viperid snakes in the area: Bothrops diporus $(\mathrm{N}=63)$, Bothrops jararaca $(\mathrm{N}=21)$ e Bothrops jararacussu $(\mathrm{N}=13)$. Active individuals were recorded from October to March, with the highest occurrence during the months of January, February and March (Figure 1). During the months of lower ambient temperatures (June, July and August), there was no record of snakes (Figure 1).

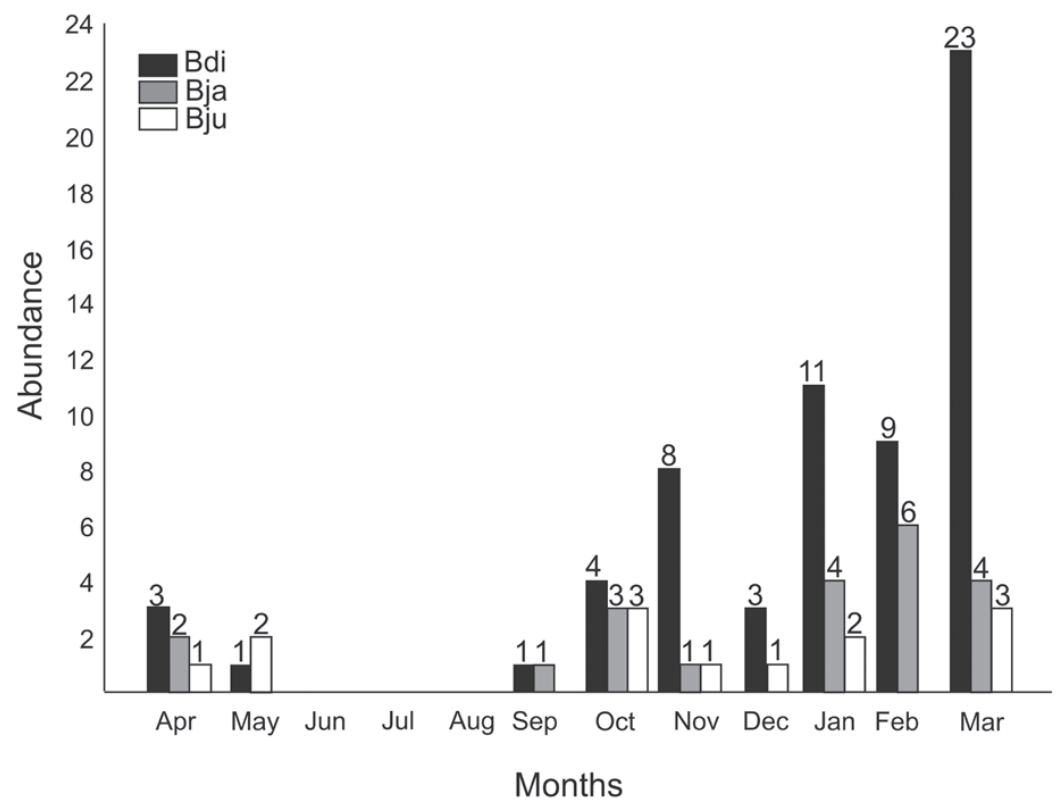

Figure 1 - Number of monthly records for the three viperid species found in Turvo State Park (Parque Estadual do Turvo), Rio Grande do Sul, Brazil, from April 2009 to March 2010, considering all sampling methods. Bdi $=$ Bothrops diporus; $\mathrm{Bja}=B$. jararaca $; \mathrm{Bju}=$ B. jararacussu.

Among the measures of temperature recorded for the study area, we chose the minimum temperature due to the higher coefficient of variation associated with this $(\mathrm{CV}=29.91 \%)$. Therefore, we compared the number of snakes encounters with minimum monthly average temperature, monthly rainfall, and monthly insolation (Total: $\mathrm{R}^{2}=0.76$, $\mathrm{R}^{2} \mathrm{aj}=0.68, \mathrm{~F}(3,8)=8.65$ and $\left.\mathrm{p}<0.05\right)$. There was a positive and significant relationship between the occurrence of snakes and minimum temperature of $\operatorname{PET}\left(\beta_{\text {Tmin }}=0.84, \mathrm{p}<0.05 ; \beta_{\text {Precipitation }}=-0.07\right.$, $\left.\mathrm{p}=0.77 ; \beta_{\text {Insolation }}=0.10, \mathrm{p}=0.72\right)($ Figures 2 and 3$)$. 


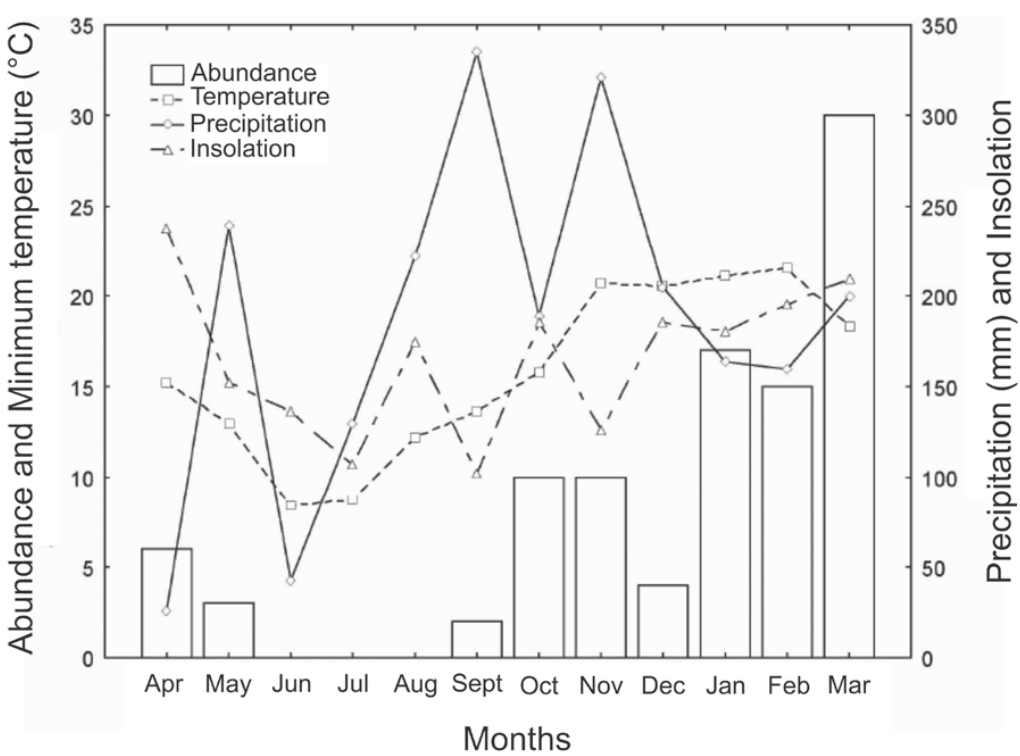

Figure 2 - Abundance of viperid snakes in Turvo State Park (Parque Estadual do Turvo), Rio Grande do Sul, Brazil, and environmental variables recorded during the present study (from April 2009 to March 2010).

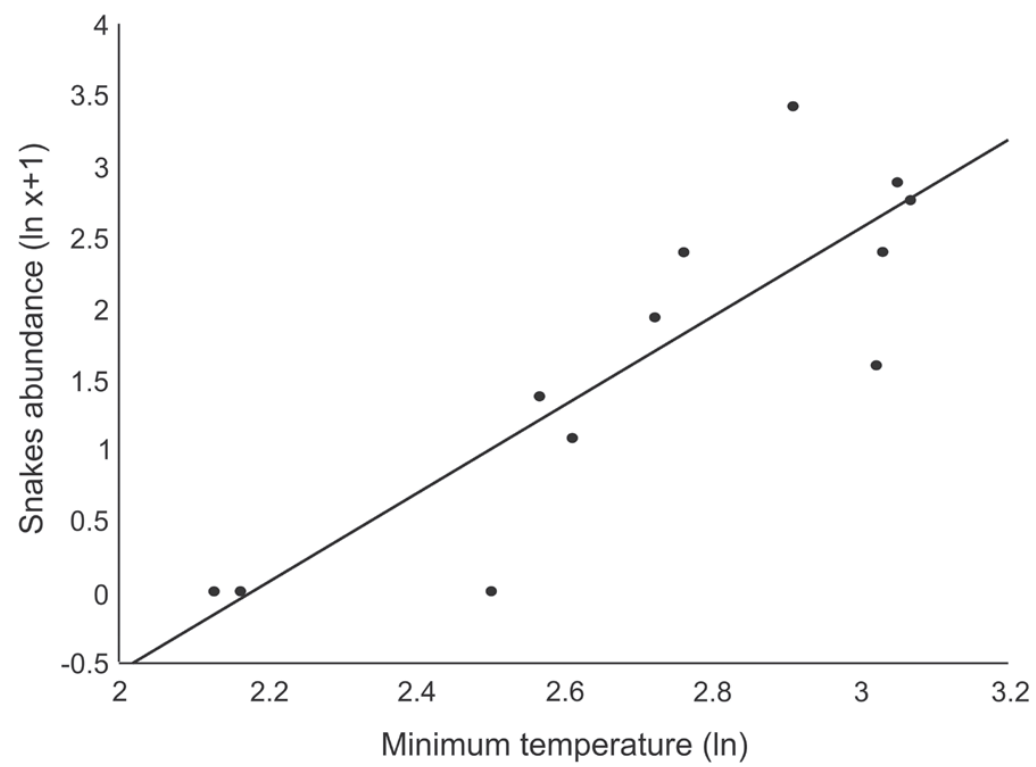

Figure 3 - Simple linear regression between abundance of snakes and the minimum environmental temperature, for viperids found in Turvo State Park (Parque Estadual do Turvo), Rio Grande do Sul, Brazil, from April 2009 to March 2010. All data were transformed into logarithm (ln).

Of the 97 viperid records, it was possible to determine if the snake was active or inactive in 86 encounters. In general, viperid snakes presented lower activity during the period between 12:00 and
15:00 (Figure 4A). Bothrops diporus was not found in just one of the sampled periods (between 13:00 and 14:00; Figure 4B); B. jararaca had the highest number of sightings in the afternoon and evening 
(Figure 4C); whereas B. jararacussu comparatively were more frequently found at night (Figure 4D). The activity rate of viperids during daytime was 0.086 snakes/minute, and 0.144 snakes/minute overnight. Bothrops diporus and B. jararaca were found mainly in degraded areas, whereas $B$. jararacussu was found almost exclusively in forest interior (Figure 5). The use of mesohabitat was significantly different among viperids (Table I).

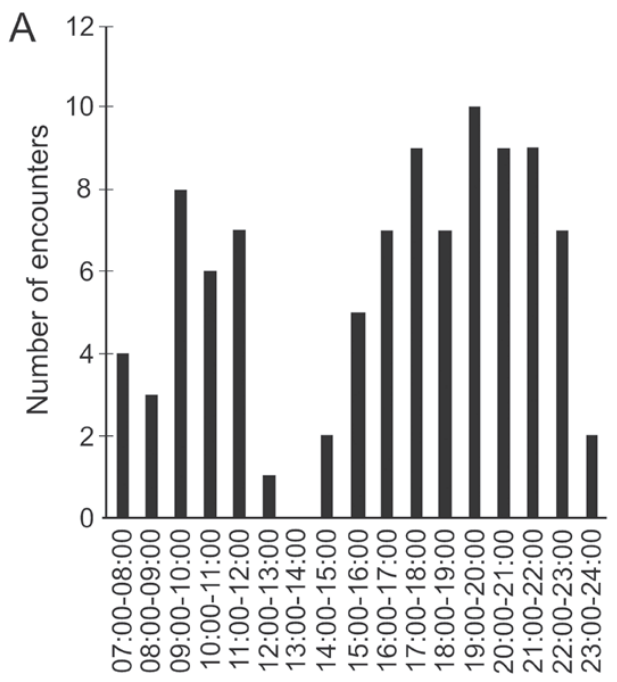

Time

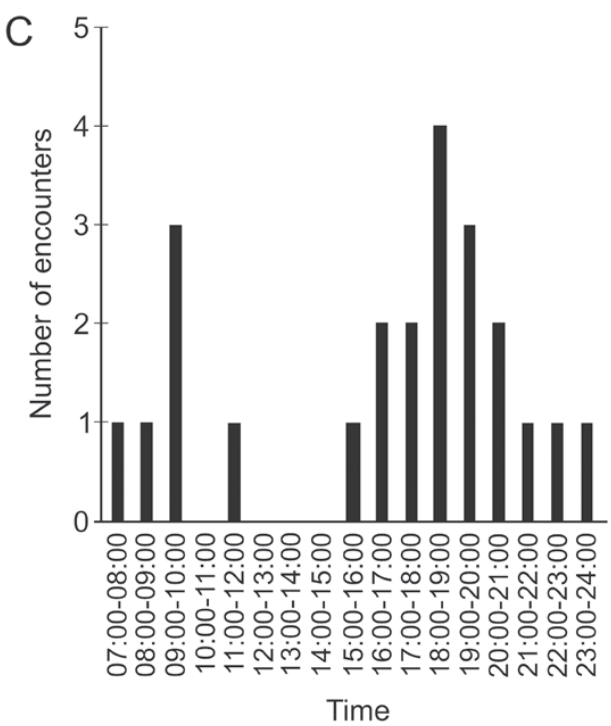

TABLE I

Results from variance analysis via data randomization to test the mesohabitat used by viperid snakes in Turvo State Park, southern Brazil, from April 2009 to March 2010.

\begin{tabular}{ccc}
\hline Sources of variation & Sum of squares & p \\
\hline Factor species & & \\
Among species & 9.47 & 0.0001 \\
Contrasts & & \\
Bdi Vs. Bja & 1.54 & 0.003 \\
Bdi Vs. Bju & 9.06 & 0.0001 \\
Bja Vs. Bju & 3.21 & 0.0007 \\
\hline
\end{tabular}
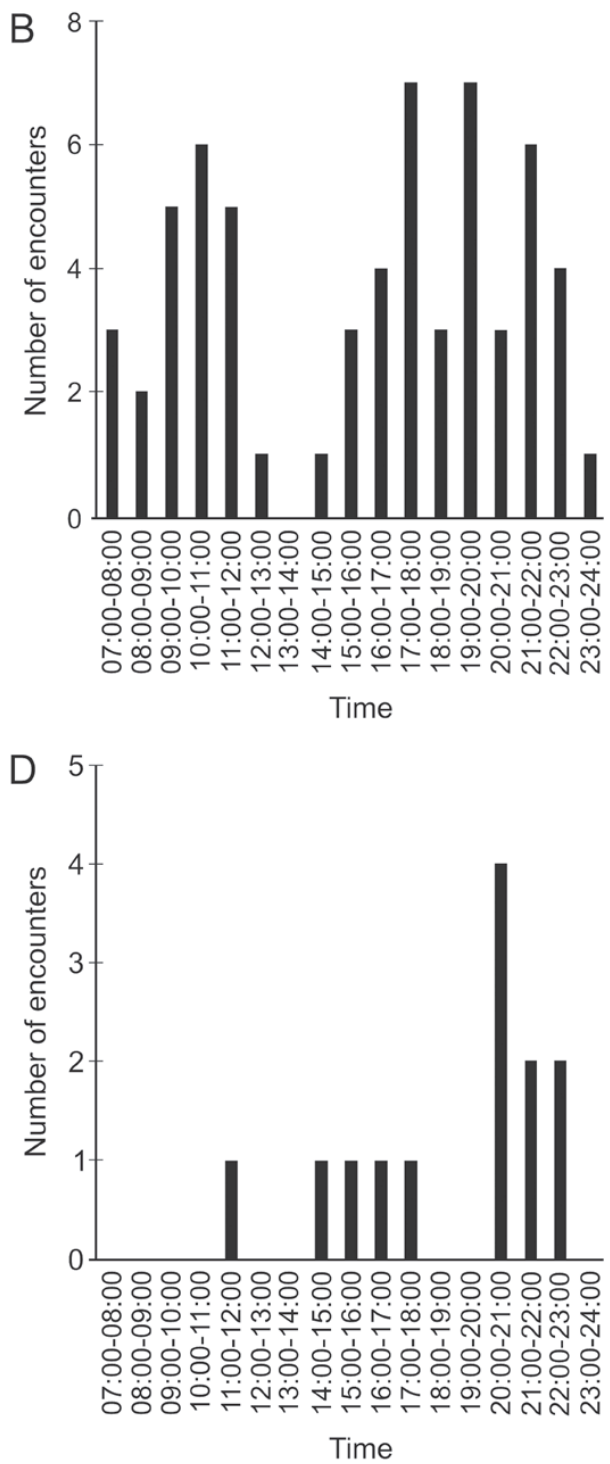

Figure 4 - Daily activity of recorded pit viper snakes, sampled from April 2009 to March 2010, in Turvo State Park (Parque Estadual do Turvo), Rio Grande do Sul, Brazil. A= all species; B= Bothrops diporus $; \mathrm{C}=$ B. jararaca $; \mathrm{D}=B$. jararacussu. 


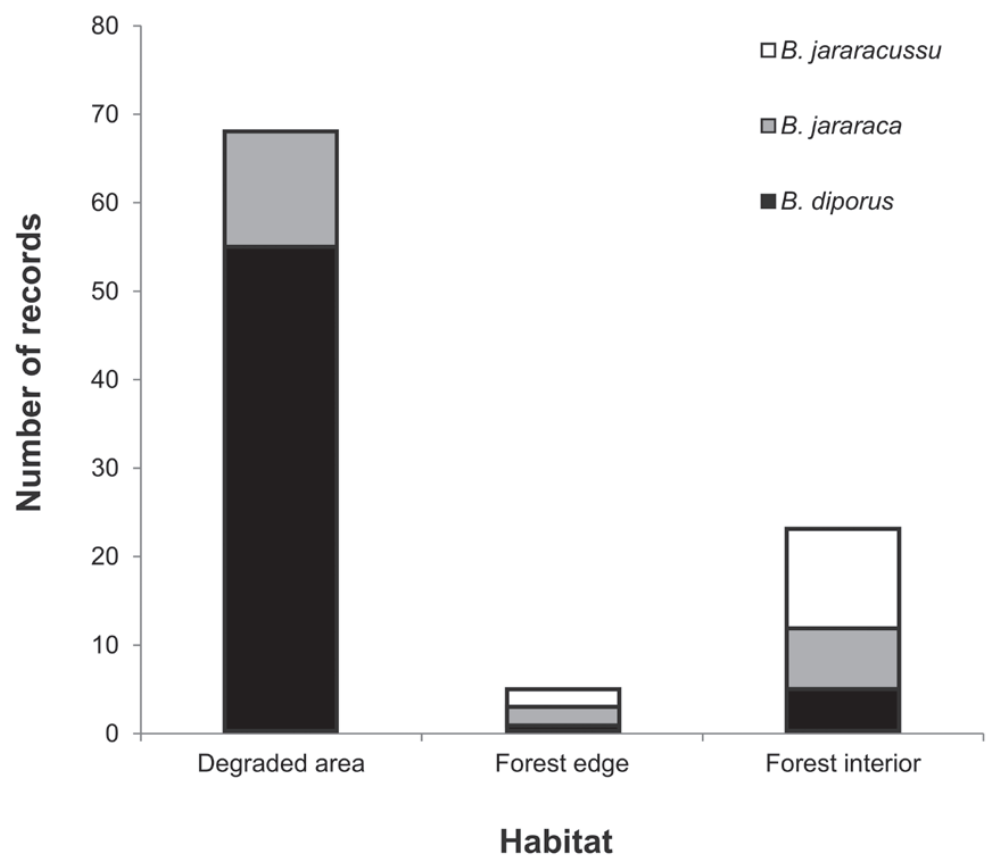

Figure 5 - Habitat use by viperid snakes in Turvo State Park (Parque Estadual do Turvo), Rio Grande do Sul, Brazil, during the present study (from April 2009 to March 2010).

\section{DISCUSSION}

The data indicated that the activity of Bothrops diporus, B. jararaca, and B. jararacussu reflected environmental seasonality, with reduced activity in the months of lower temperatures and higher activity in warmer months. Biotic and abiotic factors may influence the activity patterns of snakes, such as rainfall and temperature, prey availability, and reproductive partners (e.g., Henderson et al. 1978, Vitt 1987, Gibbons and Semlitsch 1987, Martins and Oliveira 1998, Bernarde and Abe 2006). However, snakes in general tend to vary their activity according to precipitation and temperature (see Gibbons and Semlitsch 1987). In Brazil, the variation in seasonal activity was recorded for other snakes in the southeastern Atlantic Forest (Marques et. al. 2001, 2006, Pontes et al. 2009) and Amazon (Oliveira and Martins 2001). In these locations, the increased activity of snakes was usually observed in periods with greater incidence of rainfall (e.g., Martins and Oliveira 1998, Valdujo et al. 2003, Bernarde and Abe 2006, Pontes et al. 2009). In the southern region, the seasonality is influenced by constancy of precipitation and the variation of temperature (see Maluf 2000, Mantovani and Silva 2002). Some studies indicate a trend on seasonal activity of snakes: at the subtropical region of Brazil, it may be related to the environmental temperature (e.g., Maciel et al. 2003, Winck et al. 2007).

Our data indicate that the temperature in the area influenced the seasonal activity of the viperid species, observed mainly by the lack of active snakes during the months of lower temperatures. Over the years, studies indicated low temperatures as a limiting factor for the activity of most snakes, because their metabolism is influenced by the thermal regime of the environment in which they live in (Gibbons and Semlitsch 1987). Previous studies with snakes in sites with marked temperature variation suggested the temperature as being the main factor limiting the activity of snakes in subtropical South America (Maciel et al. 2003, Hartmann et al. 2004, Winck et 
al. 2007, Giraudo et al. 2008, Hartmann et al. 2009b). The environmental effects of seasonality may act in the reproductive activity of snakes (Sun et al. 2001, Brown et al. 2002), probably due to the higher probability of survival of the offspring in warm climate (see Gibbons and Semlitsch 1987). Viperids from PET seem to present these features, since the main prey for these species (small mammals) was found throughout the entire sampled year.

Overall, our data suggest that the daily activity of the studied viperids tends to vary, with lower rates of encounter during periods with higher temperatures. Many Squamata (including snakes) adjust their activity patterns in response to changes in temperature (Nelson and Gregory 2000). Marques et al. (2001) showed the activity of $B$. jararaca and $B$. jararacussu to be mainly nocturnal. Sazima (1992) also classified B. jararaca, as a nocturnal snake. Hartmann et al. (2009b) found $B$. jararaca and $B$. jararacussu active during day and night; however, these species appeared to be more active during the night. Marques and Araújo (2011) observed an individual of $B$. jararacussu feeding during the day on a prey with predominantly diurnal activity. Oliveira et al. (2001) categorized B. atrox as a nocturnal species with occasional daytime activity. Valdujo et al. (2003) observed prevalence of nocturnal activity in $B$. pauloensis. Low rates of nocturnal snake encounters during the day could be related to the fact that these snakes could be sheltered during the day to avoid visual predators (Martins and Oliveira 1998). Our study confirmed previous data, since the proportion of encounters $B$. diporus, B. jararaca and B. jararacussu during the night was higher thant the daytime.

In this study, our data indicate exclusive occurrence of $B$. jararacussu in forested areas of PET, and the probable inability of this species to use the open vegetation and/or crops around PET. The close relation between the species and forest areas with some degree of conservation was recognized in previous studies (e.g., Hartmann et al. 2009b). However, the use of matrix areas in the vicinity of the fragments is not yet elucidated. Although B. jararacussu is not in the Brazilian List of Threatened Fauna (IBAMA 2003, Fundação Biodiversitas 2002), and in the category "Least Concern" in the IUCN Red List (IUCN 2012), the threat to Atlantic Forest environments logically consists of a direct risk to this species. The lack of knowledge on the status of populations (IUCN 2012) allied to the apparent limitation that the open areas exert on $B$. jararacussu, and to the high rates of habitat loss and fragmentation generate deep concern about the conservation and persistence of this species in natural environments.

The data presented in this study confirmed the trends from previous studies conducted in tropical climate in Brazil (e.g., Martins and Oliveira 1998, Marques et al. 2001, 2006, Oliveira and Martins 2001). Due to the large territory, Brazil has a great diversity of biomes, each with its own environmental characteristics. However, despite the great latitudinal range of viperids, the trend observed in the daily and seasonal activity remains very similar, although apparently influenced by different factors (temperature or precipitation, mostly). This trend has probably been shaped along the evolutionary time by snakes of the family Viperidae, reflecting on a similar adaptive response against different environments, with different environmental characteristics. Also, it is important to ensure the conservation of Atlantic Forest areas, to guarantee the preservation of the species reliant on forested areas (B. jararacussu).

\section{ACKNOWLEDGMENTS}

We thank the Centro de Conservação e Manejo de Répteis e Anfíbios (RAN) from Instituto Brasileiro de Meio Ambiente e dos Recursos Naturais Renováveis (IBAMA), which authorized this study (process $\mathrm{n}^{\circ}$ 18545-2); the Departamento de Unidades de Conservação (DUC), linked to the Secretaria Estadual de Meio Ambiente do Estado do Rio Grande do Sul 
(SEMA), for the research license (process $n^{\circ} 301$ ); the Instituto Nacional de Metereologia (INMET) that provided meteorological data. We are grateful to Conselho Nacional de Desenvolvimento Científico e Tecnológico $(\mathrm{CNPq})$ for the Postdoctoral fellowship grant provided to GRW (process $n^{\circ} 150855 / 2012-5$ ), and for the grant "Produtividade em Pesquisa" to SZC. We appreciated the valuable suggestions and comments made by two referees during the publication process.

\section{RESUMO}

Serpentes viperídeas são amplamente distribuídas pela América do Sul, com maior radiação ocorrendo na subfamília Crotalinae. Apesar da aparente abundância dessas serpentes ao longo da sua distribuição geográfica, alguns aspectos ecológicos permanecem desconhecidos, principalmente em áreas subtropicais. No presente estudo, avaliamos a atividade (diária e sazonal) e o uso do ambiente por Bothrops diporus, B. jararaca e B. jararacussu, em uma área de Mata Atlântica, no sul do Brasil. Observamos maior incidência de viperídeos durante os meses com temperaturas mais altas, enquanto nenhuma serpente foi encontrada durante os meses de menores temperaturas. Os dados sugerem a temperatura mínima como a variável ambiental com maior influência na atividade sazonal dessas espécies. Considerando a atividade diária, observamos uma tendência das serpentes evitarem os horários com temperaturas mais altas. Bothrops jararacussu tendeu a evitar áreas mais abertas, sendo registrada apenas dentro e na borda da mata. Comparamos nossos resultados com estudos prévios realizados em áreas tropicais, e sugerimos a atividade sazonal observada como uma resposta evolutiva, apesar de influenciada por diferentes variáveis ambientais, de acordo com a região de ocorrência.

Palavras-chave: Parque Estadual do Turvo, Rio Grande do Sul, Mata Atlântica, Bothrops, padrão de atividade.

\section{REFERENCES}

BERNARDE PS AND ABE AS. 2006. A snake community at Espigão do Oeste, Rondônia, Southwestern Amazon, Brazil. S Am J Herpetol 1: 102-113.
BLOUIN-DEMERS G AND WEATHERHEAd PJ. 2001. Thermal ecology of black rat snakes (Elaphe obsolete) in a thermally challenging environment. Ecology 82(11): 3025-3043.

Brown GP, ShIne R And Madsen T. 2002. Responses of Three sympatric snake species to tropical seasonality in northern Australia. J Trop Ecol 18: 549-568.

CAMPBELl JA AND LAMAR WW. 2004. The Venomous Reptiles of the Western Hemisphere. New York: Comstock Publishing Associates (Cornell University Press), 962 p.

CECHIN SZ AND MARTINS MRC. 2000. Eficiência das armadilhas de queda (pitfall traps) em amostragens de anfíbios e répteis no Brasil. Rev Bras Zool 17: 729-740.

Centeno FC, Sawaya RJ and Marques OAV. 2008. Snake assemblage of Ilha de São Sebastião, Southeastern Brazil: Comparison to Mainland. Biota Neot 8(3): 63-68.

Ford NB AND SEIGEL RA. 1989. Phenotypic plasticity in reproductive traits: evidence from a viviparous snake. Ecology 70(6): 1768-1774.

FUNDAÇÃO BIODIVERSITAS. 2002. Lista da fauna brasileira ameaçada de extinção. Fundação Biodiversitas, Belo Horizonte, Brasil. Available at: http://www.biodiversitas. org.br. Accessed in October 09, 2011.

GIBBONS J AND SEMLITSCH R. 1987. Activity patterns. In: Seigel RA et al. (Eds), Snakes: Ecology and Evolutionary Biology, New York: McGraw-Hill Publishing Co., p. 184-209.

GiRAUdo AR, ARZAMENDIA V, LOPES SM, QUAINI RO, PRIETO Y, LEIVA LA, REGNER SA AND URBAN JM. 2008. Serpientes venenosas de Santa Fe, Argentina: conocimientos sobre su historia natural aplicados para la prevención de ofidismo. Rev FABICIB 12: 69-89.

GREENE HW. 1997. Snakes: the evolution of mystery in nature. California: University of California Press, $351 \mathrm{p}$.

GUIZONI-JR IR, KUnZ TS, CHEREM JJ AND BÉRNILS RS. 2009. Registros notáveis de répteis de áreas abertas naturais do planalto e litoral do Estado de Santa Catarina, sul do Brasil. Biotemas 22(3): 129-141.

HARTMANN MT, HARTMANN PA, CECHIN SZ AND MARTINS M. 2005. Feeding habits and habitat use in Bothrops pubescens (Viperidae, Crotalinae) from Southern Brazil. J Herpetol 39(4): 664-667.

Hartmann MT AND Marques OAV AND AlmEIDA-SANTOS SM. 2004. Reproductive biology of the southern Brazilian pitviper Bothrops neuwiedi pubescens (Serpentes, Viperidae). Amphibia-Reptilia 25: 77-85.

Hartmann PA, HARTMANN MT AND Martins M. 2009a. Ecologia e história natural de uma taxocenose de serpentes no Núcleo Santa Virgínia do Parque Estadual da Serra do Mar, no sudeste do Brasil. Biota Neotrop 9(3): 173-184.

HARTMANN PA, HARTMANN MT AND MARTINS M. 2009b. Ecology of a snake assemblage in the Atlantic Forest of southeastern Brazil. Pap Avul Zool 49(27): 343-360.

HARTMANN PA, HARTMANN MT AND MARTINS M. 2011. Snake road mortality in a protected area in the Atlantic Forest of southeastern Brazil. S Amer J Herpetol 6(1): 35-42.

HARTMANN PA AND MARQUES OAV. 2005. Diet and habitat use of two sympatric species of Philodryas (Colubridae), in south Brazil. Amphibia-Reptilia 26: 25-32. 
HENDERSON RW, DIXON JR AND SOINI P. 1978. On the seasonal incidence of tropical snakes. Milw Public Mus Contrib Biol Geol 17: 1-15.

Huey RB, Peterson CR, ARnOld SJ ANd Porter WP. 1989. Hot rocks and not-so-hot rocks: retreat-site selection by garter snakes and its thermal consequences. Ecology 70(4): 931-944.

HutCHINSON GE. 1959. Homage to Santa Rosalia or why are there so many kinds of animals? Am Nat 93(870): 145-159.

IBAMA - InSTITUto BRASileiro DO MEIO AMBIENTE E DOS RECURSOS NATURAIS RENOVÁVEIS. 2003. Instrução Normativa $\mathrm{n}^{\mathrm{0}} 3$ de 27 de maio de 2003. Lista das Espécies da Fauna Brasileira Ameaçada de Extinção. Brasília: IBAMA.

IBGE - INSTITUTO BRASILEIRO DE GEOGRAFIA E ESTATÍSTICA. 2010. Available at http://www.ibge.gov.br/. Accessed in October 14, 2010.

INMET - Instituto Nacional de Meteorologia. 2010 Available at: http://www.inmet.gov.br/. Accessed in July 30, 2010.

IUCN - INTERNATIONAL UNION FOR CONSERVATION OF NATURE. 2012. IUCN Red List of Threatened Species. Version 2012.1. http://www.iucnredlist.org. Accessed in October 09, 2012.

LEGENDRE P AND LEgENDRE L. 1998. Numerical Ecology. Amsterdam: Elsevier Science B.V., 853 p.

MAdSEn T AND SHINE R. 1993. Phenotypic Plasticity in Body Sizes and Sexual Size Dimorphism in European Grass Snakes. Evolution 47(1): 321-325.

MALUF JRT. 2000. Nova classificação climática do Estado do Rio Grande do Sul. Rev Bras Agrometeorol 8(1): 141-150.

MACIEL AP, DI-BERNARDO M, HARTZ SM, OlIVEIRA RB AND PONTES GMF. 2003. Seasonal and daily activity patterns of Liophis poecilogyrus (Serpentes: Colubridae) on the north coast of Rio Grande do Sul, Brazil. AmphibiaReptilia 24: 189-200.

MANTOVANI W AND SiLVA SM. 2002. Vegetação e Flora. In: Ministério do Meio Ambiente (Org), Biodiversidade Brasileira: Mata Atlântica e Campos Sulinos, Brasília: Ministério do Meio Ambiente, p. 219-225.

MARTINS AR, BRUNO SF AND NAVEGANTES AQ. 2012 Herpetofauna of Núcleo Experimental de Iguaba Grande, Rio de Janeiro state, Brazil. Braz J Biol 72(3): 553-562.

Martins M, ARaúJo M, SAWAYA RJ AND NunES R. 2001. Diversity and evolution of macrohabitat use, body size and morphology in a monophyletic group of Neotropical pitvipers (Bothrops). J Zool 254: 529-538.

MARTINS MAND OLIVEIRA ME. 1998. Natural history of snakes in forests of the Manaus region, Central Amazonia, Brazil. Herpetol Nat Hist 6(2): 78-150.

May PG, Farrell TM, Heulett ST, Pilgrim MA, Bishop LA, SPENCE DJ, RABATSKI AM, CAMPBELL MG, AYCRIGG AD AND RICHARDSON WE. 1996. The seasonal abundance and activity of a rattlesnake (Sistrurus miliarius barbouri) in central Florida. Copeia 1996: 389-400.

MARQUES OAV, ALMEIDA-SANTOS SM AND RODRIGUES MG 2006. Activity patterns in coralsnakes, Genus Micrurus (elapidae), in south and southeastern Brazil. S Amer J Herpetol 1(2): 99-105.
MARques OAV AND ARAÚJO CO. 2011. Do pitvipers prey on mammals during daylight? Herpetol Notes 4: 453-454.

MARQues OAV, Eterovic A AND ENDO W. 2001. Seasonal activity of snakes in the Atlantic Forest in southeastern Brazil. Amphibia-Reptilia 22(1): 103-111.

Miller DA, CLARK WR, ARNOLD SJ AND BRONIKOWSKI AM. 2011. Stochastic population dynamics in populations of western terrestrial garter snakes with divergent life histories. Ecology 92(8): 1658-1671.

MUSHINSKY HR. 1987. Foraging ecology. In: Seigel RA et al. (Eds), Snakes: ecology and evolutionary biology, New York: McGraw-Hill Publishing Co., p. 303-334.

NeLson KJ AND GREGORY PT. 2000. Activity patterns of garter snakes Thamnophis sirtalis, in relation to weather conditions at a fish hatchery on Vancouver Island, British Columbia. J Herpetol 34: 32- 40.

OLIVEIRA MEES AND MARTINS M. 2001. When and where to find a pitviper activity patterns and habitat use of the lancehead, Bothrops atrox, in central Amazonia, Brazil. Herpetol Nat Hist 8(2): 101-110.

PIANKA ER. 1986. Ecology and natural history of desert lizards. New Jersey: Princeton University Press, 208 p.

PILlAR VD. 2006. MULTIV - Multivariate Exploratory Analysis, Randomization Testing and Bootstrap Resampling. Universidade Federal do Rio Grande do Sul, Porto Alegre, Brasil.

Pontes JAL, Figueiredo JP, Pontes RC AND RochA CFD. 2008. Snakes from the Atlantic Rainforest area of Serra do Mendanha, in Rio de Janeiro state, southeastern Brazil: a first approximation to the taxocenosis composition. Braz $\mathrm{J}$ Biol 68(3): 601-609.

Pontes JAL, Pontes RC AND Rocha CFD. 2009. The snake community of Serra do Mendanha, in Rio de Janeiro State, southeastern Brazil: composition, abundance, richness and diversity in areas with diferent conservation degrees. Braz J Biol 69(3): 795-804.

PRADO DE. 2000. Seasonally dry forests of tropical South America: from forgotten ecosystems to a new phytogeographic unit. Edinb J Bot 57(3): 437-461.

Santos TG, Kopp KA, SPIES MR, TREVISAN R AND CECHIN SZ. 2005. Répteis do Campus da Universidade Federal de Santa Maria, RS, Brasil. Biota Neotrop 5(1): 171-178.

SAWAYA RJ, MARQUES OAV AND MARTINS M. 2008. Composition and natural history of a Cerrado snake assemblage at Itirapina, São Paulo state, southeastern Brazil. Biota Neotrop 8: 129-151.

SAZIMA I. 1992. Natural history of the jararaca pitviper, Bothrops jararaca, in southeastern Brazil. In: Campbell JA and Brodie Jr ED (Eds), Biology of the Pitvipers, Texas: Selva Publ, p. 199-216.

SEMA - Secretaria Estadual do Meio Ambiente. 2005. Plano de Manejo do Parque Estadual do Turvo. Estado do Rio Grande do Sul, 345 p.

SHINE RAND BONNET X. 2000. Snakes: a new 'model organism' in ecological research? Trends Ecol Evol 15: 221-222.

STATSOFT. 1984-2006. STATISTICA 8.0: Data Analysis Software System, Electronic Manual, Oklahoma. 
Sun LX, SHINE R, ZHAO D AND TANG Z. 2001. Biotic and abiotic influences on activity patterns of insular pit-vipers (Gloydius shedaoensis, Viperidae) from north-eastern China. Biol Conserv 97: 387-398.

VAldujo PH, Nogueira C AND Martins M. 2003. Ecology of Bothrops neuwiedi pauloensis (Serpentes: Viperidae: Crotalinae) in the Brazilian Cerrado. J Herpetol 36(2): 169-176.

ViTT LJ. 1987. Communities, In: Seigel RA et al. (Eds), Snakes: Ecology and evolutionary biology, New York: McGraw-Hill Publishing Co., p. 335-365.
Winck GR, SANTOS TG AND CECHIN SZ. 2007. Snake assemblage in a disturbed grassland environment in Rio Grande do Sul State, southern Brazil: population fluctuations of Liophis poecilogyrus and Pseudablabes agassizii. Ann Zool Fenn 44: 321-332.

ZANELLA N AND CECHIN SZ. 2006. Taxocenose de serpentes no Planalto Médio do Rio Grande do Sul, Brasil. Rev Bras Zool 23: 211-217.

ZAR JH. 1999. Biostatistical analysis. Fourth edition. New Jersey: Prentice-Hall Inc., 663 p. 